\title{
Construction of a sensitive and specific lead biosensor using a genetically engineered bacterial system with a luciferase gene reporter controlled by pbr and cadA promoters
}

\section{Esmail Nourmohammadi}

Mashhad University of Medical Sciences

\section{Saman Hosseinkhani}

Tarbiat Modares University Faculty of Biological Sciences

Reza Nedaeinia ( $\nabla$ molecular_biology@mail.mui.ac.ir)

Isfahan University of Medical Sciences https://orcid.org/0000-0001-9922-7181

Hoda Khoshdel-Sarkarizi

Mashhad University of Medical Sciences

Mozhdeh Nedaeinia

Isfahan University of Medical Sciences

Maryam Ranjbar

Islamic Azad University Najafabad Branch

Neshat Ebrahimi

Cedars-Sinai Medical Center

\section{Zahra Farjami}

Mashhad University of Medical Sciences

Mohammad Nourmohammadi

Mashhad University of Medical Sciences

Ali Mahmoudi

Mashhad University of Medical Sciences

Mohammad Goli

Islamic Azad University Khorasgan Branch

Gordon A.Ferns

Brighton and Sussex Medical School

Majid Sadeghizadeh

Tarbiat Modares University Faculty of Biological Sciences

Research 
Keywords: Lead detection, Bacterial biosensor, Pollution control system

Posted Date: May 27th, 2020

DOI: https://doi.org/10.21203/rs.3.rs-18087/v3

License: (c) (1) This work is licensed under a Creative Commons Attribution 4.0 International License. Read Full License

Version of Record: A version of this preprint was published at BioMedical Engineering OnLine on October 19th, 2020. See the published version at https://doi.org/10.1186/s12938-020-00816-w. 


\section{Abstract}

Background: A bacterial biosensor refers to genetically engineered bacteria that produce an assessable signal in the presence of a physical or chemical agent in the environment.

Methods: We have designed and evaluated a bacterial biosensor expressing a luciferase-reporter gene controlled by pbrand cadA promoters in Cupriavidus metallidurans (previously termed Ralstonia metallidurans) containing the $\mathrm{CH} 34$ and p/258 plasmids of Staphylococcus aureus, respectively, and that can be used for the detection of heavy metals. In the present study, we have produced and evaluated biosensor plasmids designated $p G L 3$-luc/pbr-biosensor and $p G L 3-l u c / c a d$-biosensor, that were based on the expression of luc+ under the control of the cad promoter and the cadC gene of $S$. aureus plasmid p/258 and pbr promoter and pbrR gene from plasmid pMOL30 of Cupriavidus metallidurans.

Results: We found that the biodegradable $p G L 3-/ u c / p b r$-biosensor could be used to measure lead concentrations between 1-100 $\mu \mathrm{M}$ in the presence of other metals, including: zinc, cadmium, tin and nickel. The latter metals did not result in any significant gene expression of the reporter. The $p G L 3-$ luc/cad-biosensor was able to detect lead concentrations between $10 \mathrm{nM}$ to $10 \mu \mathrm{M}$.

Conclusions: This biosensor was found to be a specific for measuring lead ions in both environmental and biological samples.

\section{Background}

Ecological heavy metal pollution is a common problem that can exert damage to human health as well as the environment [1]. Because heavy metal pollutants may lead to harmful ecological outcomes [2], developing sensitive, efficient, rapid and cost-effective methods are necessary to efficiently screen for the presence of harmful metals in the environment. Lead $(\mathrm{Pb})$ is a toxic heavy metal that is extensively utilized around the world [3, 4]. It has been estimated that the world production of lead is more than 3 million tons per year. It causes widespread environmental contamination in the air, water, soil, and food [5]. This element can find its way through human bodies as well as animals, entering the food chain; in fish and shrimp it can accumulate in the bone, liver, gills, kidney, ovary, and muscle [6].

Environmental lead may result in an increase in vascular endothelial growth factor (VEGF) and blood concentrations [7, 8], and can lead to neurological and cardiovascular complications [9]. The reproductive system may also be affected by developmental disorders that are highly likely to occur in children [10-13]. Lead can cross the placenta and cause damage to the developing fetal nervous system [14].

The assessment and monitoring for environment heavy metal contamination is very important to prevent harm to human health. Currently, classical analytical methods, such as spectrometry, FIAAS (flow injection atomic absorption spectrometry), ion chromatography, and electrochemical techniques, are the main methods used for measuring environmental heavy metals pollution. The main disadvantage of these methods is the necessity for sample digestion under high temperature and pressure, or acidic 
conditions in which metal ions in solution are released [15]. Therefore, simpler methods for evaluating heavy metals are required. More importantly, heavy metals are found to be present in biological systems either in bioavailable/toxic or non-available/ non-toxic forms, and current measuring methods are unable to distinguish between toxic and non-toxic fractions of these elements [16]. Furthermore, these methods are both time-consuming and costly [17]. Biosensors have been developed that are an effective alternative to conventional detecting systems. These may be highly sensitivity and simple to use [18]. Cell-based biosensors are a type of biologic sensor that contain a reporter gene under the control of a promoter that is sensitive to the presence of an agent, such as environmental contaminants that include heavy metals. Biosensors are used in various designs with different reporters and promoters. At low concentration of heavy bioavailable metals, bioluminescence signals are likely to be suitable[19, 20]. They can also be applied to monitoring bioavailable concentrations of heavy metals [21-27] and piezoelectric biosensors [28-30] as enzyme-based electrochemical biosensors. One of the most obvious advantages of this method is the ability to measure the bioavailable heavy metal at very low concentrations. It is also a cost-effective and time saving method [18]. In these biosensors, the expression of a reporter gene is controlled by a promoter, such as the $p b r R$ promoter in the pMOL30plasmid of Cupriavidus metallidurans $\mathrm{CH} 34$ and cadC promoter in p/258 plasmid of Staphylococcus aureus that is sensitive to heavy metals. Most of these promoters originate from bacteria that have resistance systems against heavy metals [31, 32]. In this study, we have designed and evaluated the luciferase reporter gene expression of bacterial biosensor under the control of $p b r$ and $c a d C$ promoters in Cupriavidus metalliduransCH34 and p/258 plasmids of Staphylococcus aureus, respectively, for the measurement of lead.

\section{Results}

\section{Sequencing}

In order to ensure the integrity of the sequencing, the promoter region was sequenced in the modified plasmid (Fig.1C and 1D).

\section{Colony confirmation with PCR reaction}

PCR was performed using primers designed for the $p b r$ and cadA promoters, and the promoter sequence and regulatory gene were amplified with 634 bp for pbrand 601 bp for cadA (Fig.2).

\section{Biosensor activity of $p G L 3-I u c / p b r$}

The expression of the luciferase gene, in the presence of different concentrations of lead, showed that 1 $\mu \mathrm{M}$ of lead was the lowest concentration that could stimulate the promoter and could be distinguished from the basal expression of luciferase, and the highest measureable expression was seen at 100 $\mu \mathrm{mol} / \mathrm{L}$. A good biosensor should have two characteristics: specificity and sensitivity. According to the data obtained from our experiments, this biosensor had a high specificity, and luciferase gene was only expressed in the presence of lead. 
Biosensor specificity for lead in the presence of different concentrations of zinc $\left(\mathrm{ZnCl}_{2}\right)$, tin $\left(\mathrm{SnCl}_{2}\right)$ and cadmium $\left(\mathrm{CdCl}_{2}\right)$

The biosensor was cultured in the presence of different concentrations of zinc, tin and cadmium, and did not stimulate the pbrpromoter and expression of the reporter gene (Fig.3). Data obtained from the expression of the luciferase gene in the presence of various concentrations of tin, zinc and cadmium, indicated that these heavy metals did not stimulate the pbr promoter.

\section{Biosensor activity in the presence of different concentrations of Lead $\left(\mathrm{PbCl}_{3}\right)$}

Lead was the only metal that stimulated the pbrpromoter. In the absence of lead, the regulator gene prevents the promoter from activation. Lead ions bind to the regulator gene and inhibits its binding to the operator. As a result, the promoter is activated and the luciferase is expressed. The minimum detectable concentration of this biological sensor was approximately $1 \mu \mathrm{M}$ and a maximum is $100 \mu \mathrm{mol} / \mathrm{L}$. The expression of luciferase was no longer linear for value of lead from 100 to $200 \mu \mathrm{mol} / \mathrm{L}$ (Fig.4A).

\section{The expression of $p G L 3-I U c / p b r$-biosensor reporter gene at different times}

In order to identify the appropriate time for biosensor growth, a biosensor was cultured at different concentrations of lead for different durations (Fig.4B). The maximum expression of the luciferase gene was at $12 \mathrm{~h}$ (Fig.5A).

\section{The difference in the growth rate of $p G L 3-I u c /$ pbr-biosensor compared to $E$. coli strain DH5a}

The sensor bacteria had a recombinant plasmid containing the $p b r$ promoter region and the $p b r R$ regulatory gene. These bacteria have a greater resistance to lead than $E$. coliDH5a without plasmid. This resistance may be related to the $p b r R$ regulatory gene (Fig.5B). The resistance genes of metals have heavy metal binding motifs, they can result in the non-toxicity of these metals inside the cell, because of these proteins, the relative resistance of the cell to heavy metals.

\section{The activity of $p G L 3-J u c / c a d-b i o s e n s o r$ at the different concentrations of lead}

The lowest and highest concentrations of lead that could stimulate the expression of the reporter gene were $10 \mathrm{nmol} / \mathrm{L}$ and $10 \mu \mathrm{mol} / \mathrm{L}$ respectively (Fig. 6 and $7 \mathrm{~A}$ ).

\section{Expression of the Luciferase gene in the presence of 1 micro Molar concentration of Lead at different times}

The sensor bacteria were incubated at 0.20D $(1 \mu \mathrm{mol} / \mathrm{L}$ concentration $)$ for different times in the incubator. The expression of luciferase was measured at different times (Fig.7B). As shown in Fig. 7B, the concentration of $1 \mu \mathrm{M}$ lead can induce luciferase expression. The degree of expression increased with time, with measureable change in Luciferase levels by $2 \mathrm{~h}$ measure, and in biological sensors pollution is usually measured at low rates, we chose $2 \mathrm{~h}$ for culture of the $p G L 3-l u c / c a d-b i o s e n s o r$. 


\section{Discussion}

There are several advantages to the use of bacterial biosensors, including speed, simplicity and cost. Biological sensors containing $c a d A$ and $p b r$ promoter regions have been designed by other researchers, the optimization of this cell biological sensor with ability to measure lead comparing the $c a d A$ and $p b r$ promoters in a bioassay system was evaluated in this study. The use of biosensors or biological cell sensors containing a reporter gene controlled by promoters susceptible to the heavy metal ions can provide an efficient method to trace particular pollutants in the environment and in a biological solution[33]. The present study assessed a biosensor system for detecting lead ions through construction of a luminescent bacterial sensor containing the $l u c^{+}$regulated by the cad promoter and cadC gene in plasmid p/258 of S. aureus and the pbrpromoter and pbrR gene in pMOL30 plasmid of Cupriavidus metallidurans. $\mathrm{Pb}$ specific bacterial biosensors were formerly defined using reporter genes including lacZ, Iux,and Iuc in the transcription fusion constructs [34-36]. In our study, the luciferase reporter gene was used. Luciferases, as a set of heterogeneous enzymes, are able to produce light as a byproduct of catalyzing reactions. They are reporter genes extensively used by prokaryotic and eukaryotic organisms due to their high sensitivity and ease of detection. The quantification of the emitted light, i.e. bioluminescence, is of great importance; it can also be measured using a liquid scintillation counter ,a luminometer, or even a X-ray film [35]. It was concluded that a $p G L 3-/ u c / p b r$-biosensor can detect $\mathrm{Pb}^{+2}$ in the range of $1-100 \mu \mathrm{M}$ using the expression of firefly luciferase as a detector system, and is highly specific, with no expression of reporter in the presence of other metals such as $\mathrm{Sn}^{+2}, \mathrm{Ni}^{+2}, \mathrm{Cd}^{+2}$ are present. Moreover, this biosensor was 50 times more sensitive when compared with the previous biosensors reported by Chakraborty et al [32]. The $R$. mettalidurans $\mathrm{CH} 34$ strain has several resistance systems that can reduce the concentration of toxic substances to their non-toxic levels. A highly specific system for resistance to lead is known in plasmid pMOL30[37]. It effectively reduced the concentration of lead ions and is equipped with specific mechanisms for the transfer and separation of lead. The $p b r$ operon includes $p b r A, p b r B, p b r C$ and $p b r D$ genes in which $p b r D$ has a role as a chaperone to accumulate lead in the cell and pbrA eliminates lead ions[37]. Our results show that the $p G L 3-/ u c / p b r$-biosensor is not expressed in the presence of cadmium, zinc, ortin, indicating high sensitivity and specificity of the designed system for lead detection. One of the most important heavy metal transfer systems in Staphylococcus aureus is located in the plasmid p/258. The plasmid has an operon cadA that encodes an ATPas of type $P$, which causes resistance to metals such as cadmium, lead, zinc, copper, and tin. The expression of the cadA operon is controlled by the cadC homodimeric protein. This protein is able, in a binary manner, to bind to the promoter and metal ions, such as cadmium, lead, zinc, and tin. The cad belongs to ArsR / SmtB, a regulating protein family[38]. In our study, the luciferase gene was used as a reporter and $E$. coli strain of DH5a as a host. Our results showed that the $p G L 3-l u c /$ cad-biosensor can detect at least $10 \mathrm{nM}$ of lead and the lead toxicity was not observed until a concentration of $300 \mu \mathrm{M}$. However, the maximal expression of the reporter gene was performed at $10 \mu \mathrm{M}$. Our results are supported by the report of Liao et al that showed the regulating role of cad promoter and the cadC gene in plasmid p/258of S. aureus, the fluorescence emission was intensified with increasing $\mathrm{Cd}(\mathrm{II}), \mathrm{Pb}(\mathrm{II})$, and $\mathrm{Sb}$ (III) ions concentrations[39]. For Pb (II), just like our result in $p G L 3-I u c / c a d-B i o s e n s o r$, to induce GFP expression 
significantly, $10 \mathrm{nM}$ was the low,and $10 \mu \mathrm{Mwas}$ the maximum concentration of lead that induced significantly GFP expression[39]. The metallo regulatory $a_{3} N$ thiolate-rich site in cadC displays a practical selectivity for larger, softer heavy metal like $\mathrm{Pb}(\mathrm{II}), \mathrm{Cd}(\mathrm{II})$, although smaller boundary metal ions such as $\mathrm{Zn}(\mathrm{II})$ accommodated[40].

\section{Conclusion}

Our results show that the maximum expression of reporter gene was found in the presence of $100 \mu \mathrm{M}$ of Lead in $p G L 3-/ u c / p b r$-biosensor and $1 \mu \mathrm{M}$ of lead in pGL3-/uc/cad-biosensor. In this study, the specificity and sensitivity of the two heavy metal susceptive probes, $p b r$ and cadA, was investigated. Sensors composed of these two promoter regions were able to detect the concentration of lead between 1-100 $\mu \mathrm{M}$ and $10 \mathrm{nM}$ to $10 \mu \mathrm{M}$ of lead, respectively. For other heavy metals such as mercury, copper, nickel, manganese, zinc and cadmium, different biological sensors can be made and their presence in the environment can be measured with very high accuracy. To determine the accuracy of biosensors, a standard curve of Luciferase gene expression was plotted at different lead concentrations. The standard curve was constructed from triplicates values, we evaluated the accuracy of the biosensor with the specific concentrations that we had obtained from lead metals. By developing these sensors, the time required to identify environmental pollution can be minimized.

\section{Methods}

\section{Chemicals}

Analytical reagents, media and buffer solutions like TBE-EDTA buffer (Tris-borateEthylenediaminetetraacetic acid), $\mathrm{NaOH}$ (Sodium hydroxide), $\mathrm{CaCl}_{2}$ (calcium chloride), boric acid, Tris base, and agarose were all purchased from Merck (Germany). Fermentas (Lithuania) supplied the restriction endonucleases Nco1 and Hind3, T4 DNA ligase, and molecular ladder 10000-300bp. We also supplied the DNA polymerase (TaKaRa LA Taq ${ }^{\circledR}$. DNA Polymerase), dNTP and $\mathrm{MgCl}_{2}$ from Takara (Beijing, China). In addition, the plasmid extraction kit and primers were brought from Bioneer (Seoul, South Korea).

\section{Construction of biosensor plasmid}

pMOL30 (X71400 AJ278984) and PI258 (GQ900378.1) containing the pbrR gene (634 bp) and CadC gene (601bp) (Accession number: pbrR: WP_003103716.1 and CadC. WP_000726009, respectively, were synthesized and supplied by Millegen company. To ensure the accuracy of synthesized plasmid, the promoter region was sequenced. PG/3-control as a vector containing the Luciferase gene and E.coli strain DH5a as the host were used in our study. To obtain a large amount of pMA-T plasmid (a synthetic plasmid) which contains p-promoter sequences and the regulatory gene was sent to MilliGen, after evaluation at the NCBI site, for the synthesis of sequences. Synthesized sequences consisted of both pbr_pMA-T plasmids containing the promoter sequence of the pRR operon and the $p b r R$ regulator gene 
including; $\operatorname{cad} A \mathrm{pMS}-R Q-B s$ plasmid containing the promoter region of the cadAp and the $\operatorname{cad} A$ gene regulating gene), it was cloned to $E$. coli host. Afterwards, $p M A-T$ was extracted using plasmid extraction kit, and its quantity and quality were both examined by spectrophotometry and agarose gel, respectively, before they got digested by HindIII and $\mathrm{Ncol}$. The promoter regions with the regulator genes were also purified from the gel electrophoresis. The received sequence and $p G L 3$-control vector were cut using the same restriction enzyme ( $\mathrm{Nco} 1$ and Hind3) and ligation reaction at $37^{\circ} \mathrm{C}$ for $3-4 \mathrm{~h}$ with ligase enzyme. The firefly luciferase gene was placed under the control of the received promoter sequences and recombinant plasmids of $c a d$ and $p b r$ promoters were named $p G L 3-l u c / p b r$-biosensor and $p G L 3-/ u c / C a d-$ biosensor, respectively. Recombinant plasmids pGL3-/uc/ pbr-biosensor (Fig. 1A) and pGL3-/Uc/Cadbiosensor (Fig. 1B) were transferred to the $\mathrm{DH} 5 \mathrm{a}$ bacteria using the chemical method of $\mathrm{CaCl} 2$ and then were screened using selective plates containing antibiotic Ampicillin. After plasmid extraction, PCR was performed to detect colonies containing the promoter region of $p b r$ and $c a d A$ using primers designed for the cloned fragments. After these processes, recombinant plasmids were used to evaluating and measuring different concentrations of heavy metals.

\section{Culture of bacteria and measuring biosensor activity of Luciferase enzyme}

To study the efficiency of promoters the detection of heavy metals, a luciferase enzyme measurement performedin the presence of lead and other heavy metals such as tin, zinc and cadmium. In this process, E.coli stains carrying $p G L 3-/ u c / C a d-B i o s e n s o r$ and $p G L 3-/ U c / p b r-B i o s e n s o r$ were cultured in Luriae Bertani (LB) broth that contained $100 \mu \mathrm{g} / \mathrm{mL}$ ampicillin at $37^{\circ} \mathrm{C}$, overnight. Then $50 \mu \mathrm{l}$ from overnight grown culture of $p G L 3-/ u c / p b r-B i o s e n s o r$ for $12 \mathrm{~h}$ and $p G L 3-/ U c / C a d-B i o s e n s o r$ with optical density $\left(\mathrm{OD}_{600}\right) 0.8$ for $2 \mathrm{~h}$ were cultured in the presence of heavy metals at different concentrations [41]. Next, the culture was centrifuged at $5000 \mathrm{rpm}$ for $10 \mathrm{~min}$ at $4^{\circ} \mathrm{C}$ metals for bacterial sedimentation. Then the medium was removed, and lysis buffer was added to the plate and sonicated at low temperature. Then, the amount of luciferase expression was measured by a luminometer (Berthold Company).

\section{Statistical analysis}

All the experiments were repeated at triplicate to minimize error. The Student t- test and one-way analysis of variance (ANOVA) were used to compare the statistically significant between the two groups and each group was compared with the baseline through the same method. . Statistical significance was set at ${ }^{*} p<0.05$. Data are shown as mean values \pm standard deviation (SD). Linear regression was used to model the standard curve. Analysis of Data was performed using SPSS version 22 statistical software (IBM, Chicago, IL, USA).

\section{Declarations}

\section{Compliance with ethical standards}

\section{Ethical approval}


This article does not contain any studies with human participants or animals performed by any of the authors.

\section{Informed consent}

For this type of study, formal consent is not required.

\section{Competing interests}

The authors have declared no conflict of interest.

\section{Funding information}

This study was supported by Department of Molecular Genetics, Faculty of Biological Sciences, Tarbiat Modares University.

\section{Consent for publication}

All authors have given consent for publication

\section{Availability of data and materials}

All data generated or analyzed during this study are included in this published article

\section{Author Contributions}

MS and SH designed research; EN and RN performed research; HKS and NE analyzed data; EN and MN wrote the manuscript; $A M, M N$ and ZF performed statistical analysis; MG and MR contributed new reagents or analytical tools. GAF revising the manuscript critically for important intellectual content. All authors read and approved the manuscript.

\section{Acknowledgements:}

None

\section{Abbreviations}

Pb: Lead; VEGF: Vascular endothelial growth factor; Flow injection atomic absorption spectrometry: FIAAS; LB: Luriae Bertani; RLU: Relative luminescence units.

\section{References}


1. Adimalla N. Heavy metals pollution assessment and its associated human health risk evaluation of urban soils from Indian cities: a review. Environmental Geochemistry and Health. 2020;42(1):173-90. doi:10.1007/s10653-019-00324-4.

2. Hembrom S, Singh B, Gupta SK, Nema AK. A Comprehensive Evaluation of Heavy Metal Contamination in Foodstuff and Associated Human Health Risk: A Global Perspective. In: Singh P, Singh RP, Srivastava V, editors. Contemporary Environmental Issues and Challenges in Era of Climate Change. Singapore: Springer Singapore; 2020. p. 33-63.

3. Ali H, Khan E, llahi I. Environmental chemistry and ecotoxicology of hazardous heavy metals: environmental persistence, toxicity, and bioaccumulation. Journal of chemistry. 2019;2019.

4. Pourret $\mathrm{O}$, Hursthouse A. It's time to replace the term "heavy metals" with "potentially toxic elements" when reporting environmental research. International journal of environmental research and public health. 2019;16(22):4446.

5. Järup L. Hazards of heavy metal contamination. British Medical Bulletin. 2003;68(1):167-82. doi:10.1093/bmb/ldg032.

6. Winder C, Stacey NH. Occupational toxicology. CRC press; 2004.

7. Yu B, Zhang Y, Shukla A, Shukla SS, Dorris KL. The removal of heavy metals from aqueous solutions by sawdust adsorption-removal of lead and comparison of its adsorption with copper. Journal of hazardous materials. 2001;84(1):83-94.

8. Machoń-Grecka A, Dobrakowski M, Kasperczyk A, Birkner E, Kasperczyk S. Angiogenesis and lead $(\mathrm{Pb})$ : is there a connection? Drug and Chemical Toxicology. 2020:1-5.

9. Malik A, Ashraf MAB, Khan MW, Zahid A, Shafique H, Waquar $S$ et al. Implication of Physiological and Biochemical Variables of Prognostic Importance in Lead Exposed Subjects. Archives of Environmental Contamination and Toxicology. 2019. doi:10.1007/s00244-019-00673-2.

10. Woolf AD, Goldman R, Bellinger DC. Update on the clinical management of childhood lead poisoning. Pediatric Clinics of North America. 2007;54(2):271-94.

11. Zhou Q, Lin Y, Lin Y, Wei Q, Chen G, Tang D. Highly sensitive electrochemical sensing platform for lead ion based on synergetic catalysis of DNAzyme and $\mathrm{Au}-\mathrm{Pd}$ porous bimetallic nanostructures. Biosensors and Bioelectronics. 2016;78:236-43.

12. Dolati S, Ramezani M, Abnous K, Taghdisi SM. Recent nucleic acid based biosensors for Pb2+ detection. Sensors and Actuators B: Chemical. 2017;246:864-78.

13. Mason LH, Harp JP, Han DY. Pb Neurotoxicity: Neuropsychological Effects of Lead Toxicity. BioMed Research International. 2014;2014:8. doi:10.1155/2014/840547.

14. Meng $Y$, Tang $C$, Yu J, Meng S, Zhang W. Exposure to lead increases the risk of meningioma and brain cancer: A meta-analysis. Journal of Trace Elements in Medicine and Biology. 2020;60:126474. doi:https://doi.org/10.1016/j.jtemb.2020.126474.

15. Lemoine S, Bigot Y, Sellos D, Cosson R, Laulier M. Metallothionein isoforms in Mytilus edulis (Mollusca, Bivalvia): complementary DNA characterization and quantification of expression in 
different organs after exposure to cadmium, zinc, and copper. Marine Biotechnology. 2000;2(2):195203.

16. Vreeke M. Electrochemical biosensors for affinity assays. Part. 1997;1:39.

17. Gumpu MB, Sethuraman S, Krishnan UM, Rayappan JBB. A review on detection of heavy metal ions in water-An electrochemical approach. Sensors and actuators B: chemical. 2015;213:515-33.

18. Ejeian F, Etedali P, Mansouri-Tehrani HA, Soozanipour A, Low ZX, Asadnia M et al. Biosensors for wastewater monitoring: A review. Biosensors \& bioelectronics. 2018;118:66-79. doi:10.1016/j.bios.2018.07.019.

19. Jouanneau S, Durand MJ, Thouand Gr. Online detection of metals in environmental samples: comparing two concepts of bioluminescent bacterial biosensors. Environmental science \& technology. 2012;46(21):11979-87.

20. Martín-Betancor K, Rodea-Palomares I, Munoz-Martin M, Leganés F, Fernández-Piñas F. Construction of a self-luminescent cyanobacterial bioreporter that detects a broad range of bioavailable heavy metals in aquatic environments. Frontiers in microbiology. 2015;6:186.

21. Dong S, Yang Q, Fu Y, Zhang D, Huang T. Carbon cloth-supported cobalt phosphide as an active matrix for constructing enzyme-based biosensor. Journal of Solid State Electrochemistry. 2018;22(6):1689-96.

22. Hayat A, Marty JL. Aptamer based electrochemical sensors for emerging environmental pollutants. Frontiers in chemistry. 2014;2:41.

23. Maleki N, Kashanian S, Maleki E, Nazari M. A novel enzyme based biosensor for catechol detection in water samples using artificial neural network. Biochemical Engineering Journal. 2017;128:1-11.

24. Moyo M, Okonkwo JO. Horseradish peroxidase biosensor based on maize tassel-MWCNTs composite for cadmium detection. Sensors and Actuators B: Chemical. 2014;193:515-21.

25. Rao M, Scelza R, Acevedo F, Diez M, Gianfreda L. Enzymes as useful tools for environmental purposes. Chemosphere. 2014;107:145-62.

26. Wei W, Dong S, Huang G, Xie Q, Huang T. MOF-derived Fe2O3 nanoparticle embedded in porous carbon as electrode materials for two enzyme-based biosensors. Sensors and Actuators B: Chemical. 2018;260:189-97.

27. Zhang W, Liu Q, Guo Z, Lin J. Practical application of aptamer-based biosensors in detection of low molecular weight pollutants in water sources. Molecules. 2018;23(2):344.

28. Asadnia M, Myers M, Akhavan N, O'Donnell K, Umana-Membreno GA, Mishra U et al. Mercury (II) selective sensors based on AIGaN/GaN transistors. Analytica chimica acta. 2016;943:1-7.

29. Asadnia M, Myers M, Umana-Membreno GA, Sanders TM, Mishra UK, Nener BD et al. Ca2+ detection utilising AlGaN/GaN transistors with ion-selective polymer membranes. Analytica chimica acta. 2017;987:105-10.

30. Teh HB, Li H, Li SFY. Highly sensitive and selective detection of $\mathrm{Pb} 2+$ ions using a novel and simple DNAzyme-based quartz crystal microbalance with dissipation biosensor. Analyst. 
2014;139(20):5170-5.

31. Corbisier P, Ji G, Nuyts G, Mergeay M, Silver S. luxAB gene fusions with the arsenic and cadmium resistance operons of Staphylococcus aureus plasmid pl258. FEMS microbiology letters. 1993;110(2):231-8.

32. Chakraborty T, Babu PG, Alam A, Chaudhari A. GFP expressing bacterial biosensor to measure lead contamination in aquatic environment. Current Science. 2008:800-5.

33. Gui Q, Lawson T, Shan S, Yan L, Liu Y. The Application of Whole Cell-Based Biosensors for Use in Environmental Analysis and in Medical Diagnostics. Sensors (Basel). 2017;17(7):1623. doi:10.3390/s17071623.

34. Shetty RS, Deo SK, Shah P, Sun Y, Rosen BP, Daunert S. Luminescence-based whole-cell-sensing systems for cadmium and lead using genetically engineered bacteria. Analytical and bioanalytical chemistry. 2003;376(1):11-7. doi:10.1007/s00216-003-1862-9.

35. Tauriainen S, Karp M, Chang W, Virta M. Luminescent bacterial sensor for cadmium and lead. Biosensors and Bioelectronics. 1998;13(9):931-8.

36. Xu T, Close DM, Sayler GS, Ripp S. Genetically modified whole-cell bioreporters for environmental assessment. Ecol Indic. 2013;28:125-41. doi:10.1016/j.ecolind.2012.01.020.

37. Mergeay M, Monchy S, Vallaeys T, Auquier V, Benotmane A, Bertin P et al. Ralstonia metallidurans, a bacterium specifically adapted to toxic metals: towards a catalogue of metal-responsive genes. FEMS microbiology reviews. 2003;27(2-3):385-410.

38. Busenlehner LS, Pennella MA, Giedroc DP. The SmtB/ArsR family of metalloregulatory transcriptional repressors: structural insights into prokaryotic metal resistance. FEMS microbiology reviews. 2003;27(2-3):131-43.

39. Liao VH-C, Chien M-T, Tseng Y-Y, Ou K-L. Assessment of heavy metal bioavailability in contaminated sediments and soils using green fluorescent protein-based bacterial biosensors. Environmental Pollution. 2006;142(1):17-23. doi:https://doi.org/10.1016/j.envpol.2005.09.021.

40. Busenlehner LS, Weng T-C, Penner-Hahn JE, Giedroc DP. Elucidation of Primary (a3N) and Vestigial (a5) Heavy Metal-binding Sites in Staphylococcus aureus pl258 CadC: Evolutionary Implications for Metal Ion Selectivity of ArsR/SmtB Metal Sensor Proteins. Journal of Molecular Biology. 2002;319(3):685-701. doi:https://doi.org/10.1016/S0022-2836(02)00299-1.

41. Kumar A, Mathur R. Bioaccumulation kinetics and organ distribution of lead in a fresh water teleost, Colisa fasciatus. Environmental technology. 1991;12(8):731-5.

\section{Figures}




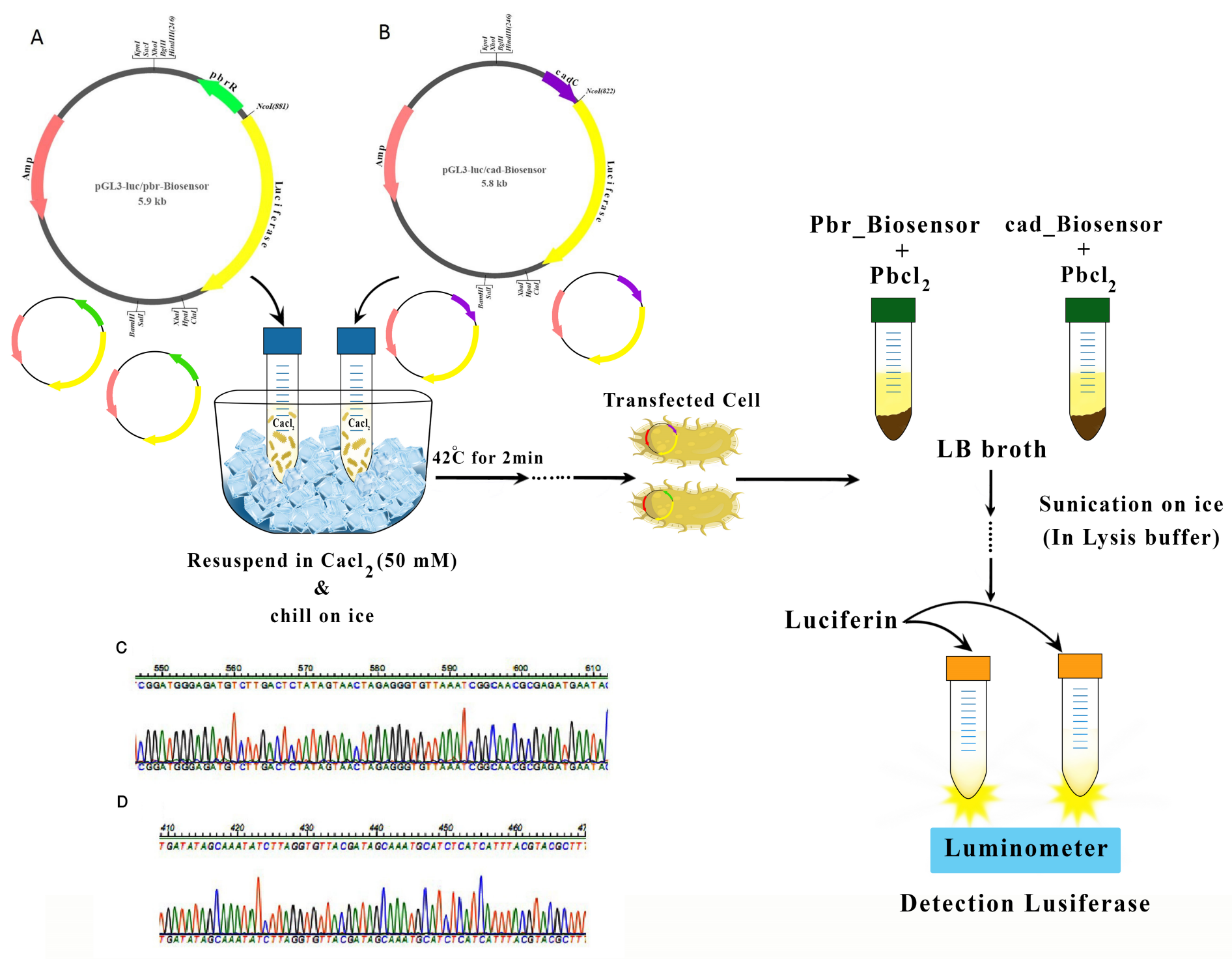

Figure 1

Simplified schematic representation of the E. coli strain DH5a transfection. A Recombinant plasmid (pGL3-luc/pbr-Biosensor). B Recombinant plasmid (pGL3-luc/cad-Biosensor). pGL3-luc/pbr-Biosensor and pGL3-luc/Cad-biosensor were transferred to the E. coli strain DH5a using the chemical method of $\mathrm{Cacl} 2$ and then were screened using selective plates containing antibiotic ampicillin. C Sequencing and integrity of synthesis sequence. D PGL3-luc/pbr-Biosensor pGL3-luc/cad-Biosensor. The promoter region was sequenced in the received plasmid. 

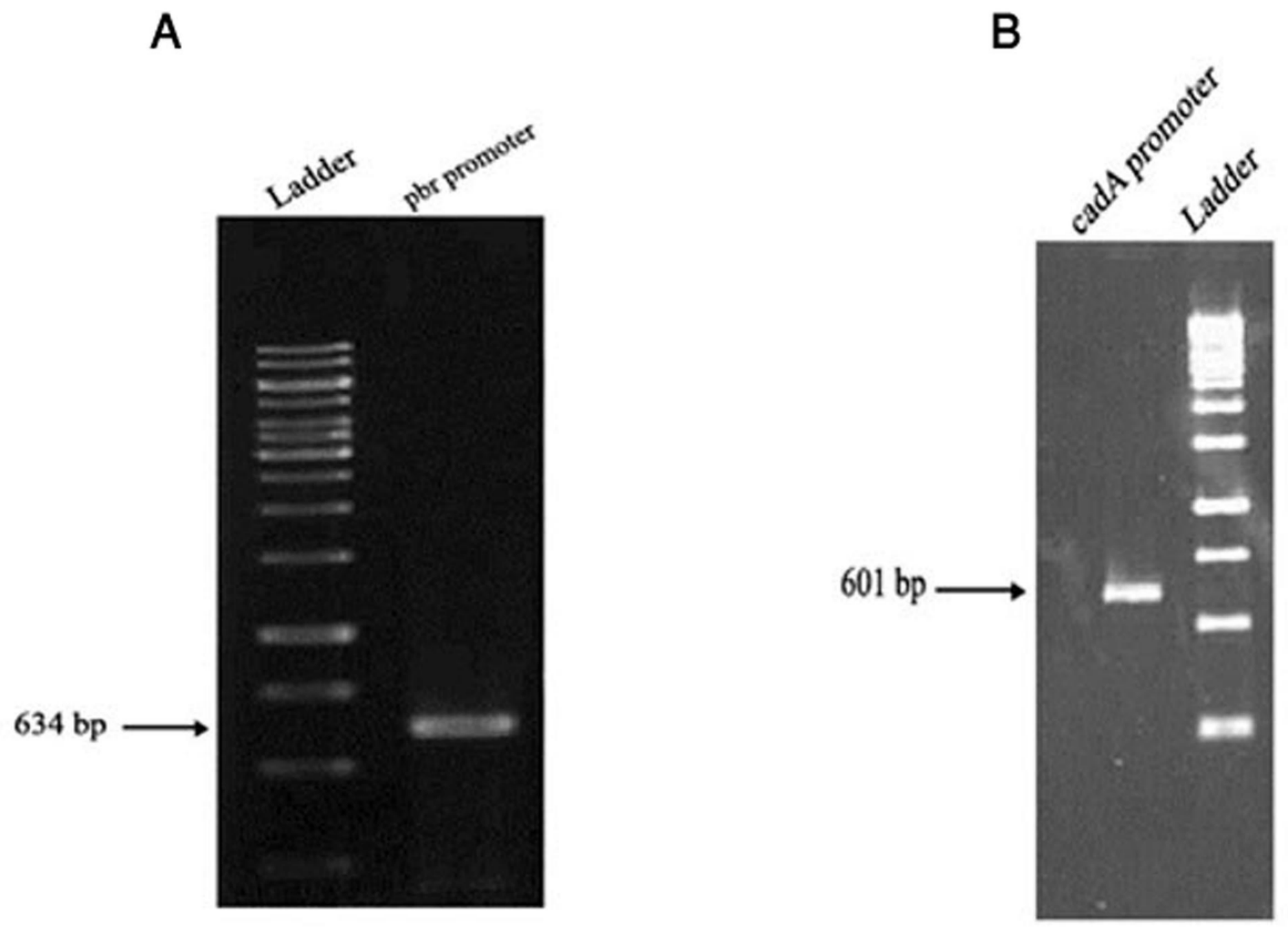

Figure 2

A The proliferation region of the pbr promoter with $634 \mathrm{bp}$. B cadA promoter with $601 \mathrm{bp}$. The promoter sequence and regulatory gene were amplified with $634 \mathrm{bp}$ for pbr and $601 \mathrm{bp}$ for cadA. $1 \mathrm{~kb}$ DNA Ladder (containing 14 linear double-stranded DNA fragments). 

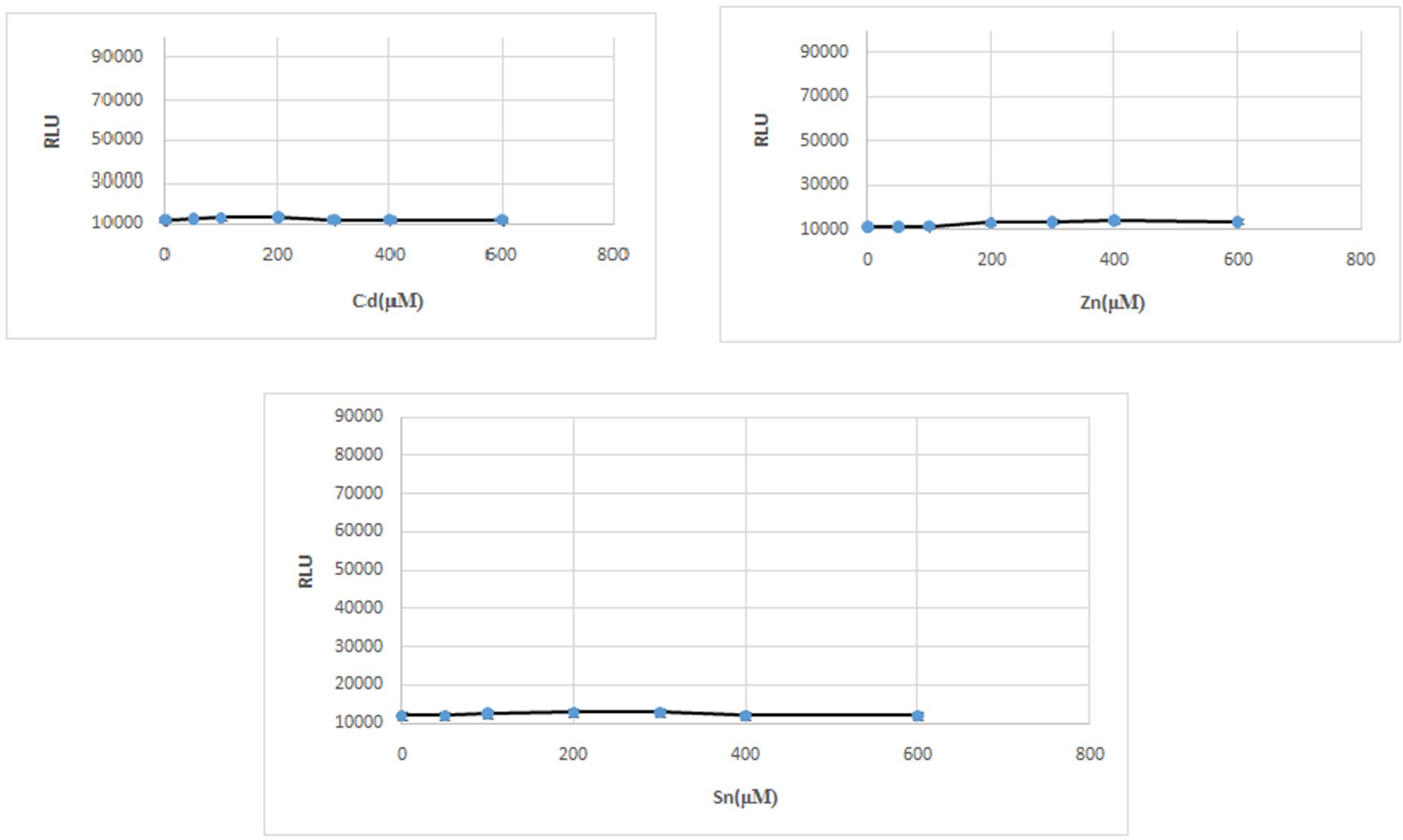

Figure 3

Expression of luciferase gene in different concentrations of zinc, Tin and Cadmium. Heavy metal had no effect on the stimulation of the pbr promoter. 

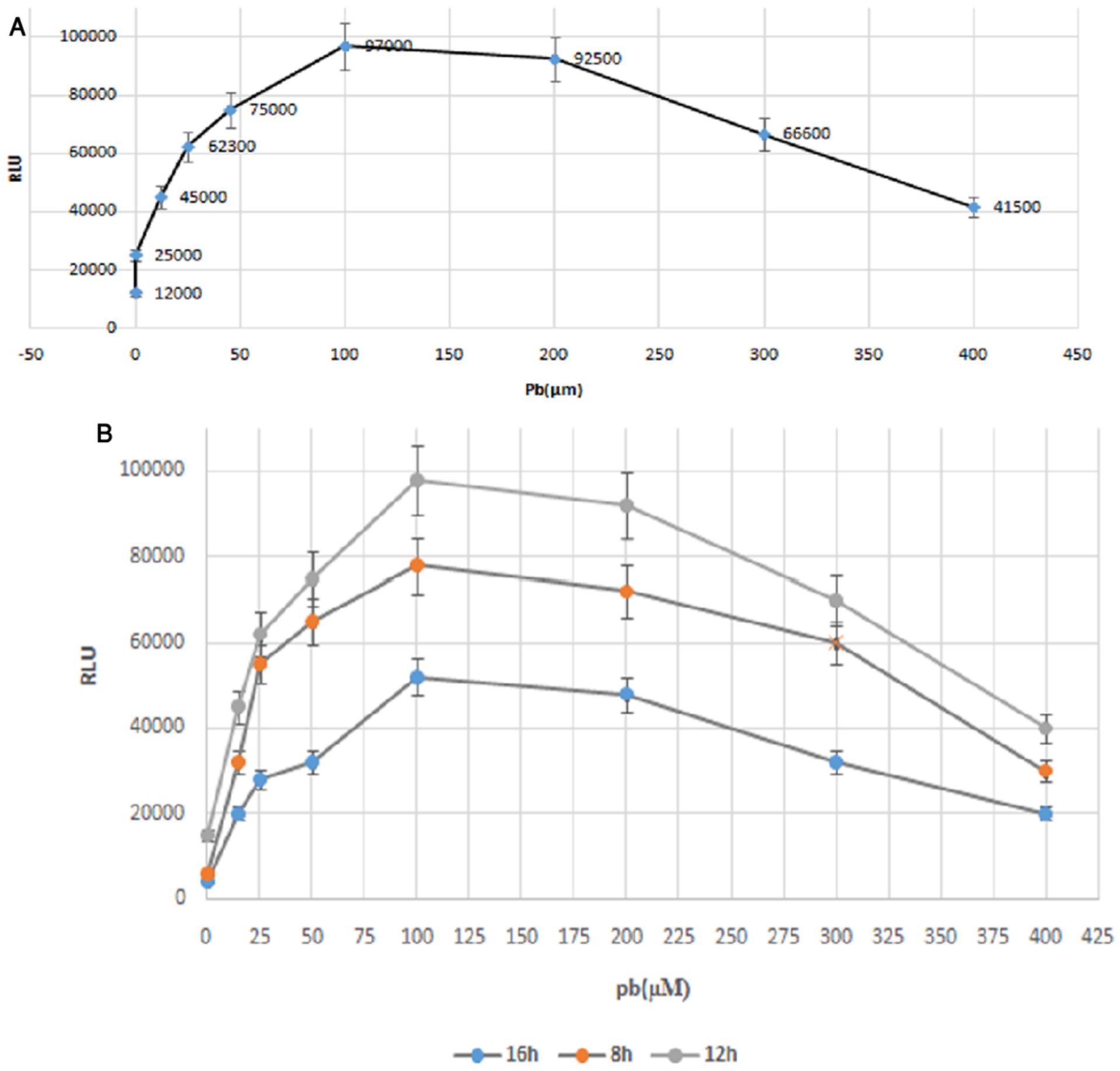

\section{Figure 4}

A Luciferase expression in different concentrations of lead. The expression of luciferase was decreased with a slight gradient from 100 to 200 micro molar. Relative luminescence units (RLU). B The expression of pGL3-luc/pbr-biosensor reporter gene at different times. 


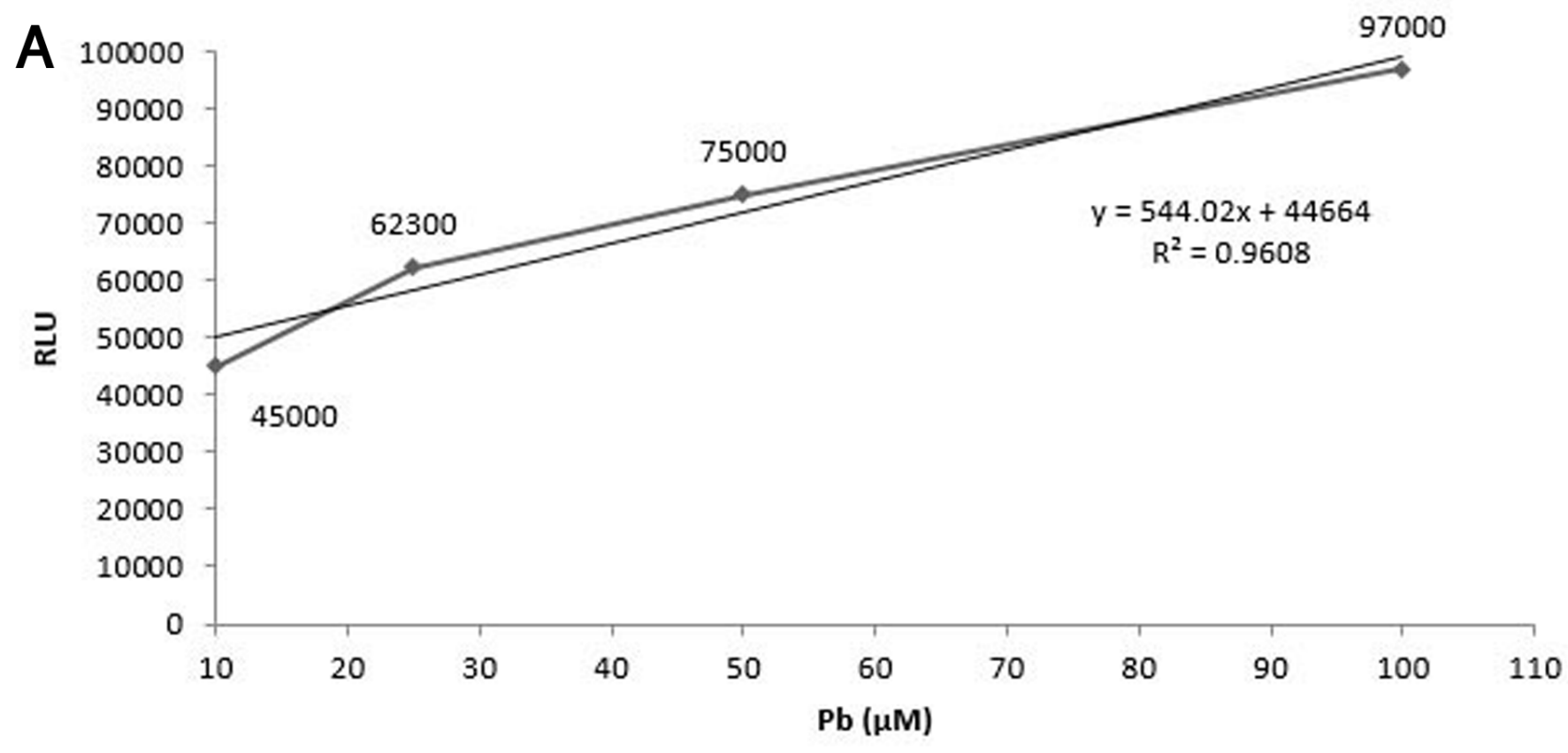

B

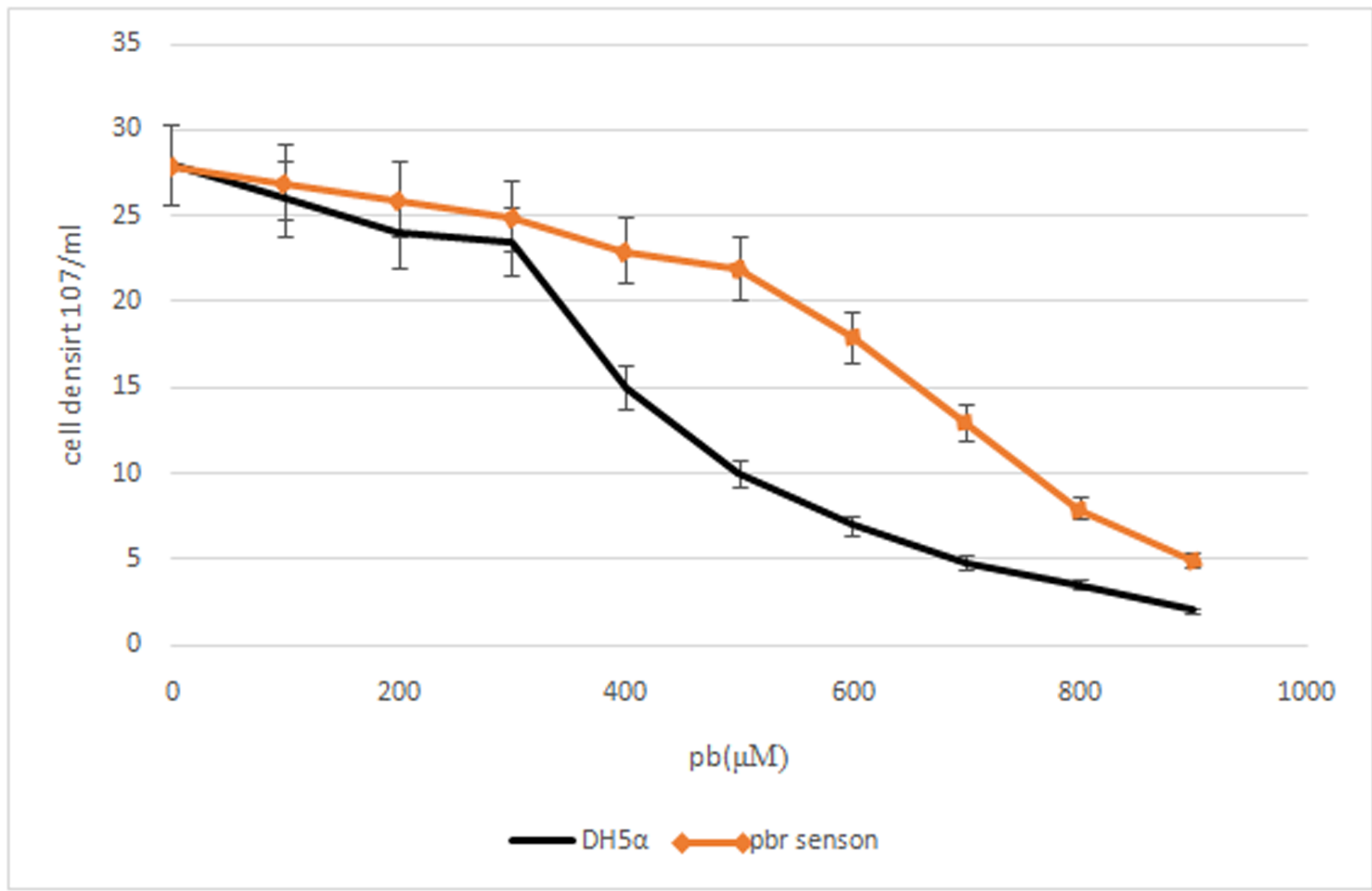

\section{Figure 5}

A Linear expression ranges of Luciferase in the presence of lead with regression coefficient R2 $=0.960$. The maximum expression of the luciferase gene was $12 \mathrm{~h}$. B Difference in the growth rate of pGL3luc/pbr-biosensor compared to E. coli strain DH5a. Resistance may be related to the pbrR regulatory gene. 


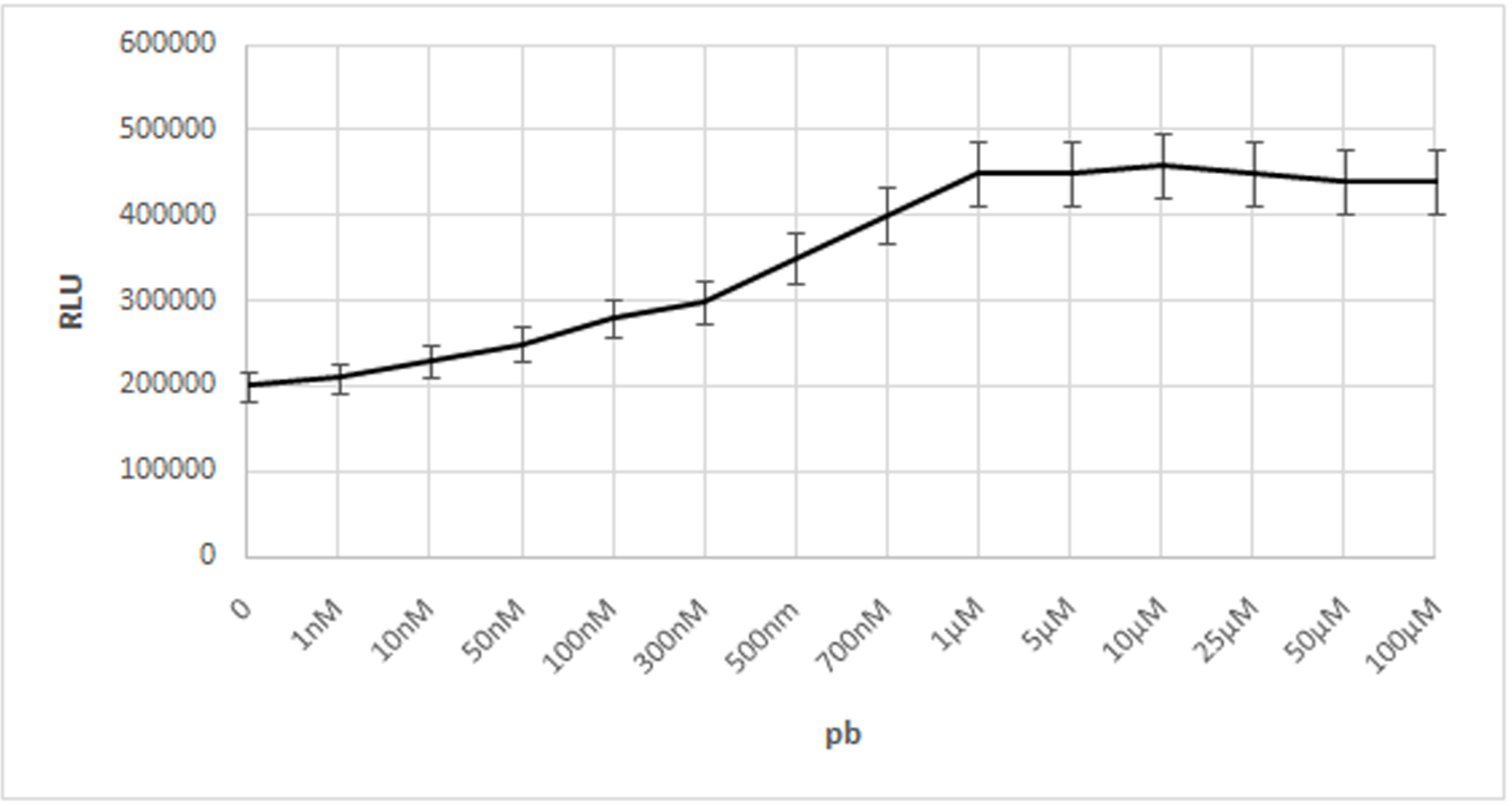

Figure 6

Expression of luciferase gene in different concentration of lead. 

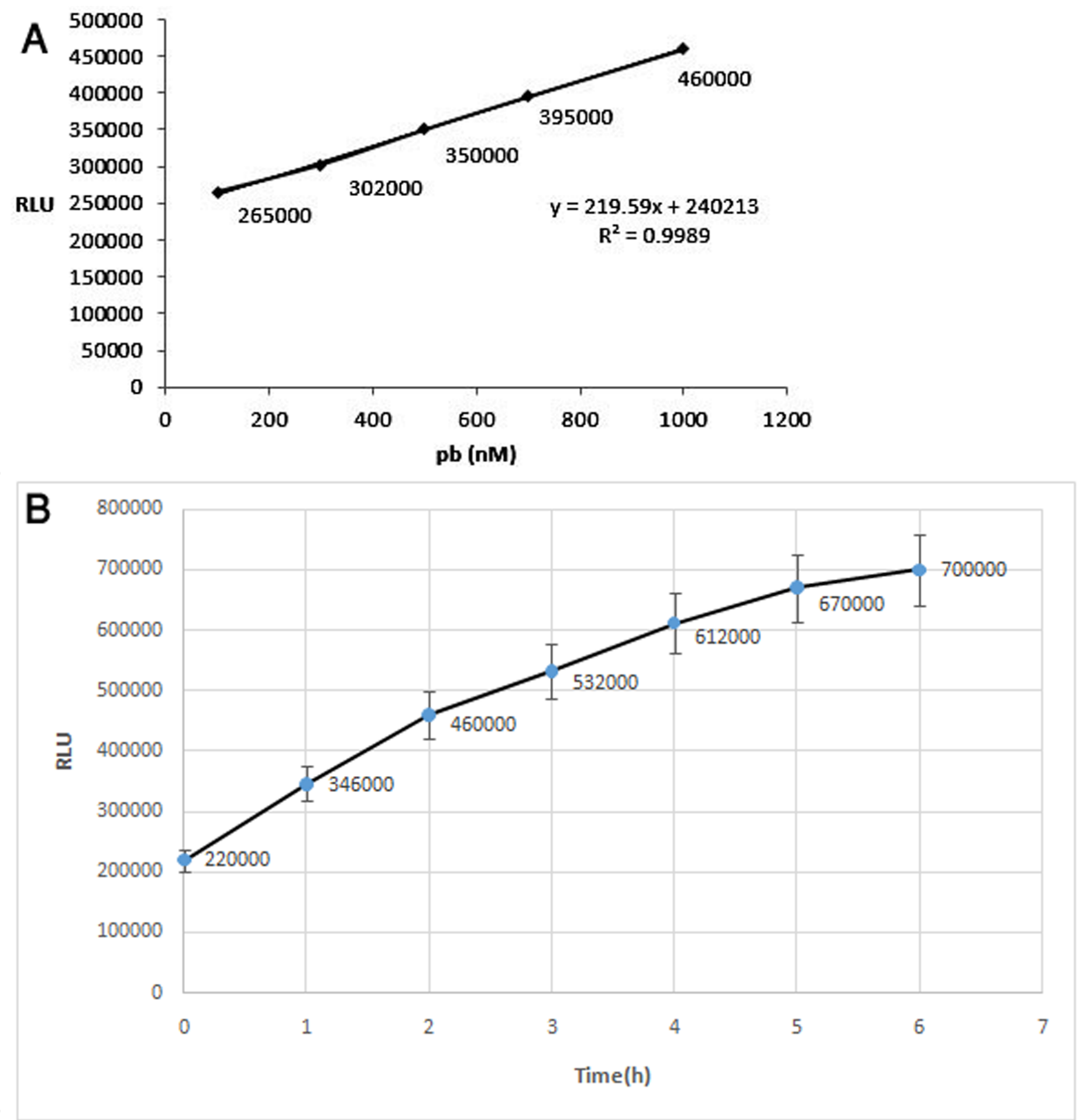

Figure 7

A linear expression ranges of Luciferase expression between 100-1000 nM concentrations of lead. B The expression of luciferase at different times at $1 \mu \mathrm{M} \mathrm{Pb}$ concentration. During $2 \mathrm{~h}$, the amount of expression is high enough to measure Luciferase, in biological sensors; the pollution is measured at low rates. 


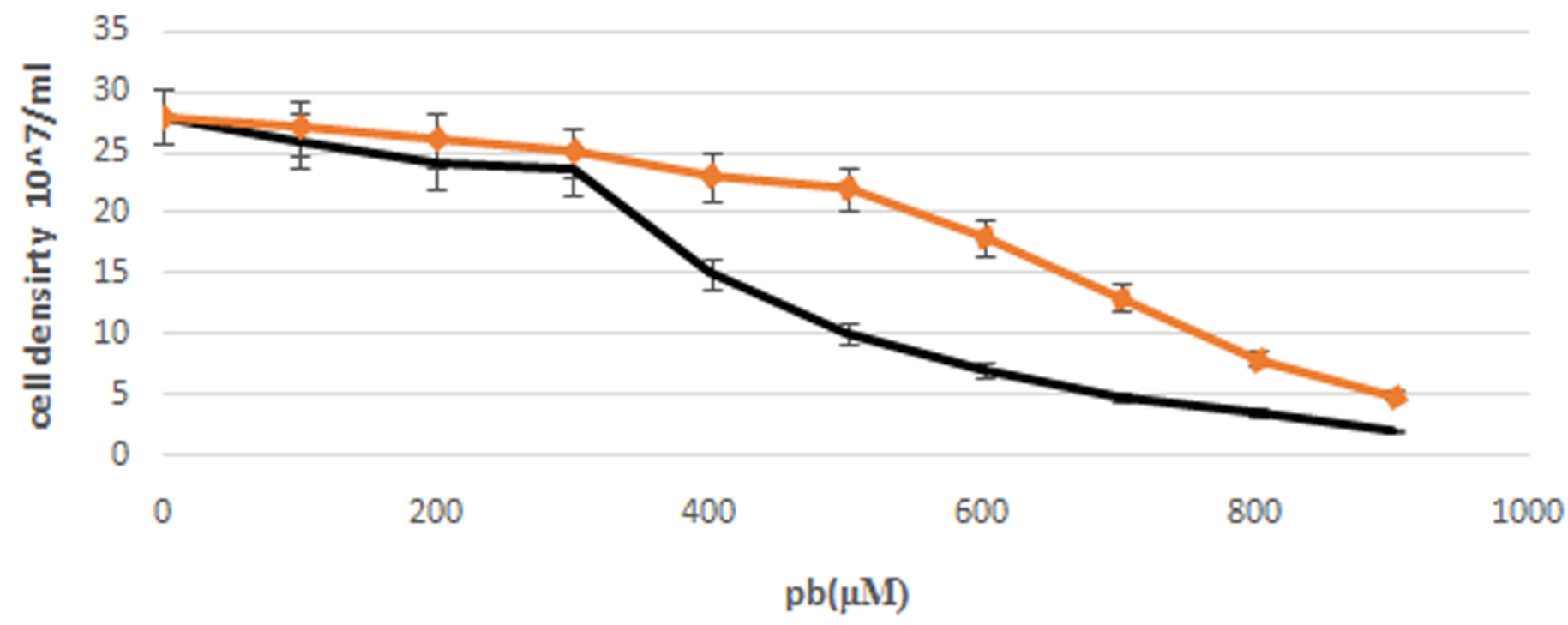

Figure 8

Difference in the growth rate of pGL3-luc/pbr-biosensor compared to E. coli strain DH5a. Resistance may be related to the pbrR regulatory gene.

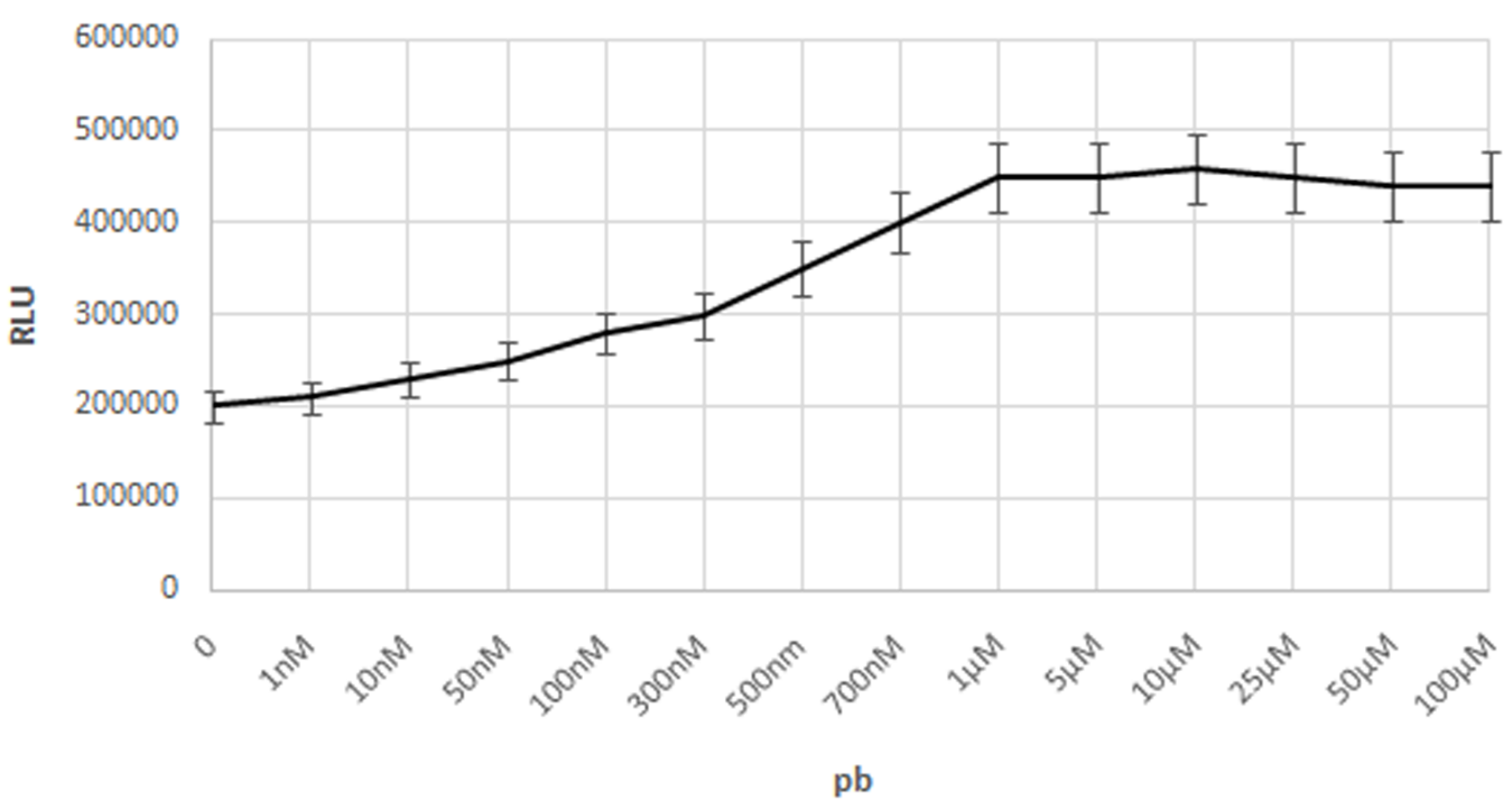

\section{Figure 9}

Expression of luciferase gene in different concentration of lead. Relative luminescence units (RLU). 


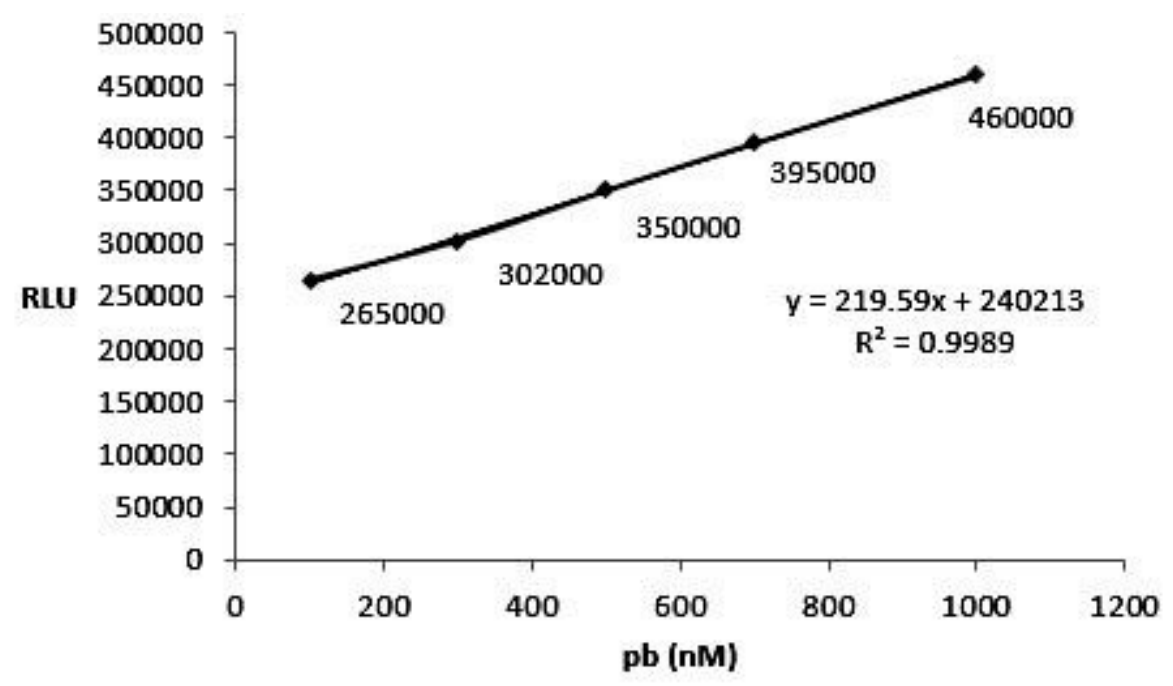

Figure 10

linear expression ranges of Luciferase expression between 100-1000 nM concentrations of lead.

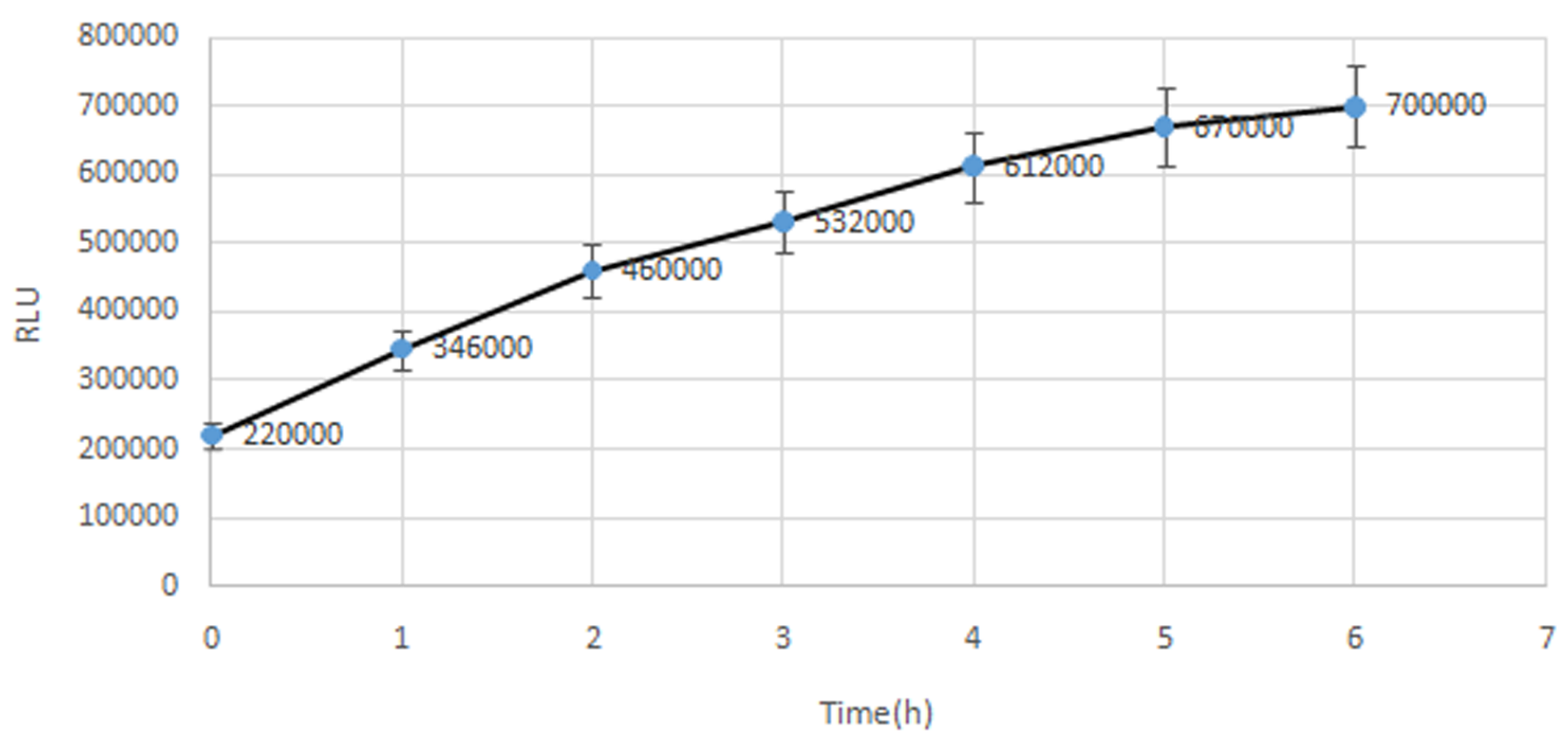

\section{Figure 11}

The expression of luciferase at different times at $1 \mu \mathrm{M}$ lead concentration. During $2 \mathrm{~h}$, the amount of expression is high enough to measure Luciferase, in biological sensors; the pollution is measured at low rates. Relative luminescence units (RLU). 